\title{
Besinning oor die twee ryke-leer
}

\author{
JH van Wyk
}

\begin{abstract}
Reflections on the theory of the two kingdoms

The question concerning the so-called two kingdoms, the kingdom of God/heaven and the kingdom of the devil/earth is as old as the history of humanity itself. Does not Christ himself refer to what belongs to Ceasar and what belongs to God (Matt 22: 21)? In this article the author first of all tries to summarise the six great theological models, with modifications, and thereafter briefly researches the South African context. He comes to the conclusion that there is only one King, one kingdom, one Word and one life; distinctions may be drawn but divisions are confusing.
\end{abstract}

\section{INLEIDING}

Wie hom besinnend besig hou met die vraagstuk van die tweeryke-leer, bevind hom in 'n mynveld van teologiese vrae wat nóu verweef is met vrae rondom die verhouding tussen algemene en besondere openbaring, natuur en genade, wet en evangelie, kerk en staat/volk, Christen en politiek. Uiteraard is dit onmoontlik om binne die konteks van een artikel aan al hierdie vrae reg te laat geskied. Ek stel my ten doel om in voëlvlug ' $n$ historiese en aktuele oorsig van die verskillende standpunte te gee, om daarna kortliks na die Suid-Afrikaanse toneel te kyk en om uiteindelik met 'n samevatting af te sluit.

Wanneer daar van 'twee ryke' gepraat word, is dit van die allergrootste belang dat noukeurig geformuleer word wat daarmee bedoel word. Algemeen gesproke is daar 'n hele paar moontlikhede waarvolgens die verhouding tussen die twee ryke omskryf kan word: isolasie (asketisme) en identifikasie (vermenging), dualisme en bipolariteit (vgl König 1979: 25). Soms is die volgende tiperinge gewaag: die Christen van die wêreld (humanisme); die Christen bo die wêreld (RoomsKatolisme); die Christen langs die wêreld (Lutheranisme); die Christen teen die wêreld (Anabaptisme); en die Christen in die wêreld (Calvinisme) (Van der Walt 1981: 247-278). Sulke tiperinge is handig om die teologiese denkpatrone te orden, maar is vanweë hulle al te growwe 
veralgemening slegs gedeeltelik bruikbaar. Ek volg tans ' $n$ ander tipering, aansluitend by dié van Durand (1978: 12-36; vgl Jonker 1987: 31).

\section{MODELLE EN MODIFIKASIES}

\subsection{Die Augustynse twee-ryke model}

Sonder twyfel was dit die groot kerkvader uit Noord-Afrika wat die eerste groot ontwerp van die twee ryke-leer gelewer het. Augustinus begin sy groot werk De civitate Dei in die jaar $412 \mathrm{nC}$, twee jaar nadat Gotiese terroriste onder Alarik die roemryke wêreldstad Rome binnegeval en vir drie dae geplunder, verwoes en verbrand het. Pelagius vertel ons iets van die vreeslike verwoesting (Marshall 1987: 123-124). Vir die inwoners was dit ' $n$ skokkende en vernietigende ervaring. Augustinus verantwoord hom teenoor die heidense propaganda dat die Christene verantwoordelik gehou moet word vir die verwoesting van die onoorwinlike stad. Hy moes deurtas na die wesenlike sin van die geskiedenis en so ontstaan die De civitate Dei as 'n monumentale 'teologie van die geskiedenis'. In die eerste tien boeke weerlê Augustinus die ongegronde meninge teen die Christelike godsdiens en wys hy daarop dat die rede vir die val van Rome geleë is in sedelike dekadensie en menslike hoogmoed. In die laaste twaalf boeke handel hy oor die ontstaan, ontwikkeling en eindbestemming van die twee stede, die stad van God en die stad van die wêreld.

Dit is duidelik dat Augustinus die twee stede identifiseer met twee lewenswyses, naamlik as ' $n$ lewenswyse na die vlees en 'n lewe na die Gees, $(14: 2 ; 14: 4,9)$, as ' $n$ lewe volgens die mens en 'n lewe volgens God $(14: 4 ; 15: 8)$, as 'n lewe uit selfliefde en 'n lewe uit Godsliefde (14: $13 ; 15: 3)$, as 'n lewe in selfroem en 'n lewe in Godsroem (14: 28); in die een stad word net gebore, in die ander ook wedergebore (15: 16, 20). Klaarblyklik trek Augustinus die verdelingslyn nie tussen hemel en aarde nie, maar dwarsdeur die skepping heen. Al word daar ook van 'n 'hemelse' stad gepraat, beteken dit nie dat die burgers daarvan (tans nog) op áárde is nie. Die stad is wel 'daarbo', maar dit bring 'hierbenede' burgers voort wat op aarde as vreemdelinge vertoef (15: 1). Daarom kan dit ook nie anders nie as dat die twee stede op aarde vervleg en gemeng is $(10: 32 ; 11: 1 ; 16: 10,54)$. Soms identifiseer Augustinus die koninkryk met die kerk (8: 24; 13: 16; 20: 9).

Die eindbestemming is die nuwe hemel en die nuwe aarde. Die ou 
wêreld sal verbygaan, 'nie deur algehele ondergang nie', maar 'deur verandering van die dinge' (20: 14), die hoedanighede van die bederflike elemente sal deur vuur vergaan, terwyl die wese van die dinge verander sal word tot 'n vernude mensheid en wêreld (20: 16). Hierdie standpunt hang nóu saam met wat Augustinus oor natuur en genade leer: Die slegte word nie weggeneem deur verwydering van die natuur nie, maar deur 'genesing en verbetering' van die gebrekkig geworde en bedorwe natuur (14: 11).

Dit is waar dat ons by Augustinus neoplatonistiese invloed opmerk en dat die denkskema hoër-laer by hom 'n rol speel (Douma 1984: 31). Tog het hy nêrens die onderskeiding civitas Dei en civitas terrena diaboli met die onderskeiding kerk en staat geparalleliseer nie. Die staat is nie uit die duiwel nie, al sou hy ook harde woorde oor onregverdige state kon sê (rowerbendes, 4: 4). Hy noem Christelike regeerders wat regverdig regeer gelukkig, wanneer hulle hulle mag diensbaar maak aan God se majesteit deur dit te gebruik vir die grootste moontlike verbreiding van sy diens, as hulle God vrees, liefhet en dien (5: 24). Daarom kan Augustinus met groot waardering verwys na die regering van keiser Konstantyn (5: 25) en Theodosius (5: 26). Hy oordeel dat op aarde daar weinig dinge beter is as vrede (wat God gee) (3:9) en daarom erken en aanvaar die hemelse stad die aardse vrede, solank dit nie die diens aan God belemmer nie (19: 17). Dit is met die begeerte vir vréde dat oorloë gevoer word (19: 12).

Die onderskeiding wat Augustinus tussen die twee ryke gemaak het, was ' $n$ spirituele (geloof en ongeloof) en geen geografiese onderskeiding nie (Douma 1984: 28, 39). Dit sny deur alle grense heen. Onduidelik is in hierdie konsep egter hoedat die verhouding kerk en staat presies daar moet uitsien. Insiggewend is nietemin dat Augustinus die dualistiese tweeryke-leer van die Manicheïsme (Faustus), met sy vyandige instelling teenoor die wêreld, met 'n verwysing na Matteus 22: 21 verwerp het. Hoogs omstrede is sy standpunt dat, op grond van Lukas 14: 21, dwangmaatreëls teen die Donatiste geregverdig is (Marshall 1987: $120-121$ ).

\subsection{Die Rooms-Katolieke natuur-genade-model}

Die ontwikkeling van die Rooms-Katolieke twee terreine-model hang, histories gesien, onlosmaaklik saam met die stryd tussen keiser en pous, met die slingergang tussen ekklesiolatrie (papalisme) en caesaropapisme. Teologies benader, vind dit sy formulering in die beroemde 
Thomistiese definisie: Gratia non tollit naturam, sed perficit. Aan die kerk kom die primaat toe omdat dit heilsinstituut is en bemiddelaar van die sakramentele genade wat die natuurlike lewensverbande tot ' $n$ hoër trap van volkomenheid moet voer (perficit); die natuurlike samelewing is die voortrap tot dit wat in die kerk deur die genade bewerk word en op sy beurt moet die kerk die oorgeblewe en onverdorwe reste van die skeppingsmatige gegewenhede (natuurreg) in die samelewing erken, ontwikkel en onder heerskappy van die genade stel (Durand 1978: 13; vgl Noordmans 1986: 428-451). Ekklesiolatrie en kerklike heerskappy oor die samelewing bly voortdurend lewensgroot gevare.

Hierdie visie kom in verskillende modifikasies na vore. Ook in die pastorale konstitusie Gaudium et spes wat tydens die Tweede Vatikaanse Konsilie vasgestel is, speel dit steeds ' $n$ rol. Weliswaar word daar gesê dat staat en kerk eie, onafhanklike en outonome terreine het, met onderlinge samewerkinge. Die kerk moet met sy leer alle terreine van menslike aktiwiteit verlig en 'n morele oordeel oor selfs politieke sake uitspreek. En so moet die kerk al wat daar aan waarheid, goedheid en skoonheid in die menslike gemeenskap gevind word, 'ondersteun' en 'verhef' (vgl hfst 4 no 76).

Hierdie hoër-laer denkskema word egter deur talle teologiese probleme omring. Allereers kontrasteer die Skrif nie natuur en genade nie, veral nie in 'n hoër-laer skema nie, maar gaan dit daarin om die skema sonde-genade. Voorts gaan dit ook nie bloot om die 'vervolmaking' van die natuur nie, soms moet die sondige menslike natuur juis gedóód word (Kol 3: 5), maar om herskepping en vernuwing, deur die oordeel heen. Ons ontvang uiteindelik méér as die herstel van die skepping in sy oorspronklike staat en méér as die ontplooiing van innerlike potensiaal wat in die skepping ingeskape is. Ons ontvang ' $n$ onvoorstelbaar nuwe (hernude) skepping. Aan hierdie eskatologiese dimensie doen die Roomse natuur-genade-leer te kort.

\subsection{Die Lutherse twee regimente-model}

Luther sluit in sy denkmodel van die twee regimente nóu by Augustinus aan (Pannenberg 1981: 125). Sy standpunt moet verstaan word teen die agtergrond van die Middeleeuse kultuur waar alles Christelik was en waar nie tussen Godsryk en Satansryk nie, maar wel tussen geestelike en wêreldlike regering in die Christendom onderskei is (Pannenberg 1981: 119). Luther wou die staat bevry van kerkoorheersing sonder om sy (die staat se) relasie tot God deur te sny (Pannenberg 1981: 122, 
124, Durand 1978: 18). So bring Luther 'n nuwe dimensie in die Augustynse onderskeid in deur te beklemtoon dat God heerskappy voer oor die civitas Dei sowel as die civitas terrena, oor kerk én wêreld. Hierdie siening, wat deur verskeie outeurs vermeld word (vgl Pannenberg 1981: 113, 125; Durandt 1978: 18-19; Douma 1984: 54, 86; Moltmann 1984: 128; Hoek 1982: 298) kan nie genoeg beklemtoon word nie. Daar moet dus goed onderskei word tussen Godsryk en Satansryk enersyds, en Godsryk en wêreldryk andersyds: die wêreldryk is nie identies aan die Satansryk nie (Hoek 1982: 286)!

Vanuit sy grondonderskeiding van wet en evangelie onderskei Luther tussen 'n geestelike regiment, waar Christus met sy evangelie (Bergrede) regeer, en 'n wêreldlike regiment, waar die owerheid regeer, uiterlike vrede skep en die bose deur die wet en swaard bedwing. Soms word die wêreldlike regiment beskryf as die regering van Gods linkerhand en die geestelike ryk as dié van Gods regterhand (Nürnberger 1975: 512), maar Douma wys daarop dat Luther self hierdie onderskeiding heel weinig gebruik en dat dit dus omsigtig hanteer moet word (Douma 1984: 60).

Luther oordeel dat die twee regimente duidelik onderskei, ja selfs geskei moet word. Maar beteken dit dat die twee regimente waterdig van mekaar afgesluit mag word, dat kerk en staat geen raakvlakke besit nie, dat die owerheid net na die menslike rede en nie ook na die evangelie moet luister nie, dat die kerk geen profeties kritiese funksie teenoor die staat besit nie, dat daar ' $n$ dubbele moraal, naamlik ' $n$ Christelike privaatmoraal en burgerlike beroepsmoraal moet wees, dat onderdanigheid aan die status quo beklemtoon word ten koste van hervorming daarvan, dat die relevansie van die evangelie geïndiwidualiseer eerder as gesosialiseer word, en, ergste van alles, dat die koningsheerskappy van Christus oor kerk én kosmos radikaal vereng word?

Inderdaad is hierdie en soortgelyke vrae aan die Lutherse teologie gestel (vgl Gollwitzer 1976: 92-93). Die kritiek van Barth het in hierdie verband die verste gegaan met die stelling dat die gebrek aan geestelike weerstand by die Duitse Christene teen die Nazisme teruggevoer kan word na Luther se dwaling (dualisme!) in verband met wet en evangelie, wêreldlike en geestelike orde (Barth 1945: 113). Almal stem natuurlik nie saam met hierdie oordeel van Barth nie. Rothuizen (1962: 88, 89, 1978: 190) meen dat daar by die Duitse Christene nie te veel isolasie nie, maar te veel identifikasie ('konfusie') tussen kerk en staat was. Nürnberger sê dat hy van 'geen teologiese tradisie weet wat meer rede het om rassisme vanuit sy diepste teologiese fondamente as kettery te 
verwerp, as die Lutherse nie' (Van der Walt 1983a: 73). Pannenberg wys daarop dat Luther se onderskeiding nie 'n vrypas tot staatsabsolutisme bied nie (1981: $113 \mathrm{vv}$ ), hoewel die moontlikheid vir skewe ontwikkeling gegee is $(1981: 114,117)$ sodat Barth dus relatief korrek is (1981: 115, 127). Tog, oordeel Pannenberg, bly Luther in gebreke om die positiewe relasie tussen koninkryk van God (eskatologie) en koninkryk van die wêreld (politiek) aan te dui (1981: 126, 127, 129); daarby vind ons by Luther nêrens enige inspirasie om die politiek te transformeer deur die magtige visie op die eskatologiese koningskap van Christus wat die wêreld reeds verlig nie (1981: 130).

Vergeleke met Augustinus het Luther vordering gebring: (1) naas twee ryke praat hy ook van twee regimente; (2) naas Christelike diens aan die geestelike regiment (kerk) is daar ook Christelike diens aan die wêreldlike regiment (owerheid); (3) die owerheidstaak is begrens en strek hom nie uit oor die geestelike lewe van mense nie (Douma 1984: $54-62)$.

En Luther se dualisme dan? Staan die kerk dan langs die wêreld, die geloof naas die politiek? Navorsers het met 'n hele reeks verwysings na Luther oortuigend aangetoon dat hierdie beeld van die teologie van Luther ' $n$ vertekende beeld is (Douma 1984: $70 \mathrm{vv}$ ). Luther plaas die geloof beide in sy prediking èn in sy teologie midde-in die politiek! Tot selfs die Bergrede! Maar hy waak daarteen om geloof en politiek te identifiseer; hy onderskei duidelik tussen wat Christus doen en wat ons doen. Luther se onderskeiding van twee regimente is egter onvoldoende: In 'n plurale samelewing is daar veel méér 'regimente' (Douma 1984: 84-85). Dit is ook veel beter om van één ryk van Christus te praat, met daarby ingesluit verskillende regimente (Douma 1984: 87).

Kritiek vanuit die Lutherse teologie self het, veral tydens en sedert die Tweede Wêreldoorlog, nie uitgebly nie. In hierdie verband moet die naam van Dietrich Bonhoeffer eerste genoem word (vgl Rothuizen 1969: $340-353$; 1985: 116-131). Dit is waar dat ons by hom ook nog lees van 'twee ryke' wat nie vermeng of geskei mag word nie, naamlik die ryk van die gepredikte Woord van God en die ryk van die swaard, die ryk van die kerk en die ryk van die wêreld, die ryk van die geestelike amp en die ryk van die wêreldlike owerheid (Bonhoeffer 1966: 101, 355, 374). Tog begin hy indringende kritiek lewer op wat hy noem 'die denke in twee ruimtes', 'n Christelike en 'n wêreldlike ruimte (1966: 208-220). Geen Christen-wees is moontlik buite die werklikheid van die wêreld om en geen werklike wêreld is moontlik buite die werklikheid van Jesus Christus om nie (1966: 213). Hy meen dat in hierdie 
verband veel vrugbaarder van 'laaste' en 'voorlaaste' dinge gepraat kan word (1966: $128 \mathrm{vv}$ ). As daar onderskei moet word, dan eerder tussen die vier 'mandate' naamlik arbeid, huwelik, owerheid en kerk (1966: $220 \mathrm{vv}$ ). Niks, maar dan totaal níks, val buite die heerskappy van Christus nie (1966: 348). Die heerskappy van Christus oor die owerheid beteken egter nie die heerskappy van die kerk oor die owerheid nie (1966: 368). Wel het die kerk 'n 'politieke verantwoordelikheid' (1966: 371-373). In een van sy beroemde gevangenskapsbriewe sou hy formuleer dat die kerk pas kerk is as hy 'daar is vir ander'; die kerk moet meewerk aan die wêreldlike take van die gemeenskapslewe, nie heersend nie maar helpend en dienend (Bonhoeffer 1970: 415).

Nog ' $n$ Lutherse teoloog by wie die Lutherse twee regimente-leer ' $n$ modifikasie ondergaan, is Helmuth Thielicke (vgl Zahrnt 1967: 197-210). Uit die kritiese vrae wat Thielicke (1965a: 589-610) aan Luther stel in verband met die twee regimente-leer, is dit duidelik dat hy nie daarmee onverdeelde instemming betuig nie. Veral belangrik is die vraag of die eskatologie in Luther se beskouiing sterk genoeg deurwerk, en word die politieke strukture nie te haastig met die wil van God vereenselwig nie? Thielicke voer aan dat in die verlossingswerk van Jesus Christus die eskatologiese wending in die geskiedenis reeds voltrek is en is die 'nuwe aeoon' in ons midde, maar daarnaas bestaan die 'ou aeoon' nog. Daar is dus diskontinuïteit tussen die ou en die nuwe aeone. As Christene leef ons in 'n interim, 'n oorgang, 'n spanningsveld.

Twee gedragspatrone kan hiervolgens dadelik uitgeskakel word: politieke radikalisme wat rewolusionêr vooruitgryp op die voleindigde koninkryk van God, en valse konserwatisme wat hom by die bestaande neerlê asof God nog niks in die wêreld verander het nie. Hierteenoor stel Thielicke sy gedagte van kompromis (1965b: $56 \mathrm{vv}$ ), wat hy verbind met sy konsep van Noagitiese orde. Die liefdesgebod behóórt volledig gerealiseer te word, maar dit kán nie omdat die struktuurwette van die wêreld dit hokslaan. Kragtens die Noagitiese verbond aksepteer God nie die aardse wette nie maar tolereer en gebruik dit. Die kompromis soek dus na 'n ewewig tussen God se absolute eise en dit wat in die strukture haalbaar is.

'n Vraag wat hom in hierdie verband vanself na vore dring, is of Thielicke nie ' $n$ te groot plek afstaan aan die Noagitiese verbond ten koste van Christus nie. Waarom neem God se openbaring in Christus nie 'n sentrale plek in nie (Zahrnt 1967: 209-210)?

'n Laaste Lutherse teoloog wat, veral onder invloed van Barth, die 
twee regimente-leer onder skerp kritiek gebring het, was Helmut Gollwitzer. Die telkens voorkomende vrae word deur Gollwitzer herhaal: Raak die evangelie net persone of ook verhoudinge? Word die dinamiek van die evangelie nie te veel op die indiwidu en te min op die samelewing betrek nie (Gollwitzer 1976: 92)? Word die onderhouding van die ordeninge nie belangriker as die verandering daarvan nie (1976: 92)? Wat word van die taak van die kerk by Luther (Gollwitzer 1964: 17 vv)? Verloor dit nie sy kritiese funksie nie (Gollwitzer 1976: 93)? En veral: Wat kom daar tereg van die heerskappy van Jesus Christus in die politiek? Is dit dan nie waar dat élke lewensverband onder die heerskappy van Christus staan en dat ons óral met Hom te doen het nie (Gollwitzer 1964: 43, 52)?

Dit is duidelik dat Gollwitzer (1982: $140 \mathrm{vv}$ ) vanuit sy aksent op die allesomvattende betekenis van die koninkryk van God tot ' $n$ kritiese waardering van die tradisionele Lutherse standpunt met sy dualisme moes kom, ofskoon Gollwitzer nie daarmee die dualiteit van kerk en staat wou opgee nie (vgl Schelhaas 1984: 44-46).

\subsection{Die Gereformeerde Christokratiese model}

Soos Luther onderskei Calvyn tussen 'aardse dinge' (bv staatsbestuur) en 'hemelse dinge' (bv koninkryk van God) $(2,2: 13)$. Daar is onder die mense 'n tweërlei regering: die een geestelik (regnum spirituale), die ander burgerlik (regnum politicum). Daar is in die mens as 't ware twee wêrelde waaroor verskillende konings en verskillende wette regeer (3, 19: 15). Dit is opvallend dat Calvyn oor die burgerlike regering handel in dieselfde boek waarin hy oor die kerk handel as 'n uiterlike hulpmiddel waardeur God ons tot die gemeenskap met Christus roep en bewaar. Die kerk regeer oor die innerlike en die burgerlike regering oor die uiterlike. Die geestelike ryk van Christus en die burgerlike regering verskil baie van mekaar sodat dit dwaas is om die ryk van Christus in hierdie wêreld te soek en op te sluit (4, 20: 1). Alhoewel die twee soorte regerings onderskeie is van mekaar, stry hulle nie met mekaar nie: Die ryk van Christus begin immers reeds hier op aarde die beginsels van die hemelse koninkryk in ons te werk: Anersyds het die burgerlike regering ook 'n godsdienstige verantwoordelikheid deur die godsdiens te beskerm en die gesonde leer en die kerk te verdedig $(4,20$ : 2-3). Die wet van God, veral die tweede deel wat oor naasteliefde handel, is 'die ware en ewige reël van geregtigheid' wat in alle tye vir alle volke voorgeskrywe is; aan alle volke is daar volle vryheid om vir 
hulle nuttige wette te maak op voorwaarde dat dit 'volgens die ewige beginsel van die liefde' sal wees $(4,20: 15,18)$. Baie belangrik is sy opmerking dat die burgerlike regering 'n roeping is wat voor God heilig en wettig is $(4: 20,4)$.

Of Calvyn die twee regimente-leer volkome verbreek het, is 'n ope vraag (Van der Walt 1981: 265), maar daar kan min twyfel daaroor bestaan dat hy dit deurbreek het (Durand, 1978: 23-24, Van den Berg 1961; Hoek 1982: 301-303). Hy verbind wet en evangelie, kerk en staat, wêreld en koninkryk veel nouer as Luther. Dit is waar dat die terreine hulle eie funksies en bevoegdhede besit, maar daar is tussen hulle duidelike verbande, en, wat uiters belangrik is, beide staan onder die heerskappy van Christus. Geen gebied beskik oor 'n eiewetlikheid nie, omdat die ewige wet van God oral geld.

'n Modifikasie op die standpunt van Calvyn is te vind by A Kuyper, 'n standpunt wat ook in Suid-Afrika weerklank gevind het in ten minste drie ondersteunende proefskrifte in hierdie verband: AP Treurnicht (1957) oor die verhouding van staat tot kerk by Kuyper, SCW Duvenage (1962) oor die verhouding kerk tot volk en PW Buys (1970) oor die onderskeiding organisme en instituut as antwoord op die volkskerk.

Bekend en beroemd is Kuyper se woord dat 'geen duimbreedte' van die menslike lewe onttrek mag word aan die heerskappy van Christus nie - woorde wat reeds by Calvyn in 'n ietwat ander konteks terug te vind is $(3,15: 8 ; 3,19: 13)$. Die vraag is egter presies hoe hierdie Christokratiese uitspraak waar gemaak moet word (vgl Douma 1984: 88-135; Thielicke 1966: 737-744). Kuyper onderskei tussen algemene en besondere genade en oordeel dat die algemene genade sy uitgangspunt vind in God se handhawing van die oorspronklike skepping waarin die staat sy oorsprong vind. Die kerk vind sy oorsprong in die besondere genade van Woord en wedergeboorte. Hoe oefen Christus nou sy koningskap in staat en kerk uit? Só dat die koningskap van Christus as Verlossingsmiddelaar hom op die kerk rig en sy koningskap as Skeppingsmiddelaar op die wêreld.

Maar hoe kan Christus se koningskap nou in die wêreld gerealiseer word? Hierop antwoord Kuyper met verwysing na die feit van 'n pluriforme samelewing, die onderskeiding van kerk as instituut en as organisme en die beginsel van soewereiniteit in eie kring. Daar is, om te begin, nie net twee terreine (kerk en staat) nie, maar 'n veelvormigheid van lewenskringe, elk met sy eie bevoegdheid en funksie. So is die kerk 'n lewenskring naas die staat. Die kerk moet egter onderskei word 
as kerk-as-instituut en kerk-as-organisme: Eersgenoemde bepaal hom by Woordverkondiging en sakramentsbediening en nié by politiek nie, terwyl laasgenoemde tot vergestalting kom in die vorm van Christelike organisasies, waaronder die Christelike politieke party. Die koningskap van Christus in die politiek word dus sigbaar deur middel van die Christelike politieke party.

Hierdie denkontwerp van Kuyper, wat inderdaad waardevolle aspekte bevat, byvoorbeeld 'n relativering van staatsgesag, word egter deur' $n$ paar fundamentele kritiekpunte ondergrawe. Eerstens moet die vraag gestel word of so 'n dualistiese kerkbeskouing Skriftuurlik verantwoord kan word. Mag 'n Christelike politieke party, Christelike universiteit en Christelike kunsvereniging nog 'kerk' genoem word (Douma 1984: 125; vgl Duvenage 1962: 63, 291)? Tweedens staan die kerk-as-instituut nie in direkte verhouding tot die staat nie (vgl Duvenage 1962: 247), wat daarop neerkom dat ons by Kuyper feitlik niks hoor van die profetiese roeping van die kerk teenoor die staat nie (Van Rooyen, 1964: 122-124, 136). Die kerk (as instituut) mag seker nie 'n politieke program voorskryf nie, maar mag dit dan nie 'n morele oordeel oor 'n politieke program uitspreek nie? 'n Derde leemte by Kuyper is dat in gevalle waar 'n Christelike politieke party ontbreek, soos in Suid-Afrika, of waar dit nie kan bestaan nie, soos in Rusland, die vraag na die universele koningsheerskappy van Christus in die lug hang en daarby aan die politiek van die dag die vryheid laat om outonoom te handel (vgl Durand 1978: 26).

Die Christokratiese model van K Barth vertoon ' $n$ eie signatuur. Dit hang saam met sy strewe om die twee ryke-leer op te ruim en rus op sy Christologiese fundering van die staat en sy siening op die verhouding van wet en evangelie (vgl Zahrnt 1967: 182-196). Barth probeer die dualisme van Luther oorkom deur veel sterker Christosentries te dink. Hy kyk nie vanuit die skepping of sondeval na die staat nie, maar vanuit Christus en die verlossing, vanuit die koninkryk van God. Die staat is nie ' $n$ produk van die sonde nie, maar 'n ordening van die Goddelike genade. Die staat staan onder die heerskappy van Jesus Christus en besit gevolglik geen eiewetlikheid nie, alhoewel dit 'n eie inhoud, waardigheid, funksie en doelstelling het. Ten grondslag aan hierdie denke lê Barth se siening oor die verhouding tussen evangelie en wet: Die wet is die gestalte van die evangelie. Dit is nie waar dat in die wêreld met die wet en in die kerk met die evangelie gewerk word nie; nee, vir beíde geld die evangelie.

In sy Christengemeinde und Bürgergemeinde van 1946 verduidelik Barth 
sy gesigspunte aan die hand van die beeld van twee konsentriese sirkels en die analogie-model: die Christelike gemeente vorm die binneste sirkel en die burgerlike gemeente die buitenste, met Jesus Christus en die koninkryk van God as gemeenskaplike middelpunt. Die verhouding tussen die twee 'gemeentes' (kerk en staat) is analogies van aard. Deur sy eksemplariese bestaan en deur sy verkondiging moet die kerk die staat herinner aan die koninkryk van God sodat die staat spieëlbeeld en gelykenis daarvan word. Die regte staat moet in die regte kerk sy oerbeeld en voorbeeld vind - 'n siening wat Barth dan met talle voorbeelde toelig. Saamgevat: die staat is 'n skepping van Christus, 'n instrument van God se genade, 'n reflekterende spieëlbeeld van die kerk, binne die wêreldomvattende heilshandelinge van God.

'n Christen moet dus in sy politieke keuses altyd vir daardie moontlikhede kies waaruit die analogie die duidelikste sal blyk. Dit beteken hoegenaamd nie die vorming van 'n aparte 'Christelike politieke party' nie aangesien die begrip 'Christelik' net op die kerk van Christus betrekking kan hê. Die kerk is, as sprekende en verkondigende kerk, deur prediking en kanselafkondiginge, gerig op die politieke vrae van die dag. Deur sy eksemplariese eksistensie is die kerk 'n politieke faktor en 'n bron van vernuwing in staat en maatskappy.

Uiteraard het die visie van Barth heelwat kritiek, veral van Lutherse kant, ontlok. So is hy verwyt dat hy van die evangelie 'n nuwe soort grondwet vir die ryk van die wêreld maak wat net een politieke bestel duld; hy is gekritiseer omdat die voorbeelde in sy analogie-model taamlik willekeurig is; veral ook dat sy denke mank gaan aan erkenning van die geskiedenis-kategorie en les bes dat dit onmoontlik is om nie een of ander vorm van 'n twee ryke-leer daarop na te hou nie, waaraan dan natuurlik die juiste interpretasie gegee moet word (vgl Zahrnt 1967: 194-196).

Ek sou hier nog baie graag op die teokratiese denke van AA van Ruler - deur Thielicke (1966: 744-756) selfs as 'ekstreme teokrasie' getipeer - wou wys, maar die artikel word dan te lank. Ek volstaan met die opmerking van Moltmann dat die teokratiese ideaal van Van Ruler nie misverstaan moet word as klerikalisme of kerklike staat nie, maar neerkom op ' $n$ ordening en vormgewing van die staatkundige lewe vanuit Christus, die evangelie en die Woord van God (in Aalders 1973: 82). Kerk en staat is twee gestaltes van één koninkryk en in die een koninkryk gaan dit vir God om behoud en redding van die volle werklikheid. 
In Suid-Afrika is noue aansluiting by Van Ruler gevind deur veral JHP van Rooyen (1964) en B Engelbrecht (1978 en 1982).

Ten slotte verwys ek hier slegs na HM Kuitert (1985: 143, 150; 1987: 40-46) se resente en gekwalifiseerde verdediging van 'n twee ryke-leer, van God se 'twee maniere van besig wees' met mens en wêreld, maar daarmee is ook reeds afskeid geneem van die Christokratiese model waarin enersyds duidelik onderskei maar andersyds nie totaal tussen die ryke geskei word nie.

\subsection{Die Anabaptistiese wêreldvermydingsmodel}

Wanneer na die Anabaptistiese wêreldvermydingsmodel verwys word, moet, veral wat die sestiende eeu betref, goed onderskei word tussen die radikale libertinisme en die minder 'dolsinnige' Dopers. So het Calvyn immers gedoen (Balke 1977: 345-346).

By die Doperse rigting vind ons seker die mees krasse vorm van 'n twee ryke-leer denkbaar (vgl Balke 1977: 261-313). Die kerk leef in totale breuk met die wêreld en Christene moet hulle afskei van elke verontreiniging met die gruwels van die wêreld. Nie in die heiliging van die wêreld nie, maar in die vermyding van die wêreld is die Christen se roeping geleë.

Hierdie wêreldbeskouing het duidelike konsekwensies vir die staatsbeskouing en politieke etiek. In die Doperse visie is die owerheid gegee om die orde te handhaaf in die wêreld wat in die mag van die Bose lê. Politiek val buite die gesigsveld van die Nuwe Testament en die evangelie bevat beginsels om die burgers van die koninkryk van die hemel te regeer, maar nie vir die wetgewing van ' $n$ wêreldlike staat wat in die bose lê nie. Dit is ook ongeoorloof vir 'n Christen om 'n owerheidsamp te beklee. Doodstraf kom in gedrang en in ooreenstemming met Christus se woorde in die Bergrede, moet die aflê van ' $n$ eed van die hand gewys word. Pasifisme en weerloosheid is wat die Bybel van ons vra. Oorloë en bloedvergieting, vergelding en wraak pas nie by 'n Christen nie. Die wet van God, die liefdeswet, eis liefde tot God en liefde tot die naaste (Van Wyk 1984: 79-80).

Dat hierdie kritiese bejeëning van 'n owerheid en alles wat daarmee saamhang, maklik tot anargisme aanleiding kon gee, spreek vanself.

Dat daar by die Dopers 'n sosialistiese tendens aanwesig was, kan nie ontken word nie. In hulle ekonomiese etiek val die aksent egter op rentmeesterskap en mededeelsaamheid en nie soseer op die gemeen- 
skap van goedere nie; so het ook nie almal privaatbesit verwerp nie (Menno Simons).

Die Dopers was natuurlik nie sonder énige relasie met die maatskappy nie. Maatskappykritiek het nie ontbreek nie. Hulle wou die oorspronklike Christendom herstel en ontdoen van die verwêreldliking van die Konstantinisme. Hulle was optimisties dat die liefdeswet onderhou kan word en dat Christene ooreenkomstig die leer van Christus en die apostels sou kon leef. Hulle wou die koninkryk en sy geregtigheid sigbaar realiseer. 'n Kompromis met die sondige wêreld en bestaande sosiale orde was uitgesluit. Waar die sosiale orde nie gekersten kan word nie, is 'n aparte Doperse staat tot stand gebring waar die koninkryk soveel moontlik vergestalt is.

Enigsins verbasend is die ambivalensie van die Doperse radikalisme in hierdie verband: Dit vertoon beide uiterstes van pasifisme en rewolusionisme. Naas vredeliewende Dopers is daar die gewelddadige Dopers wat nie gehuiwer het om selfs na die swaard te gryp ten einde die koninkryk van God te probeer realiseer nie. Veral die Dopers te Munster was van oordeel dat die gelowiges die Here moes help om sy oordeel oor die goddeloses te voltrek.

Tereg oordeel Balke (1977: 275) dat die Doperse dualisme nie (Grieks-) metafisies verstaan moet word nie, maar wel (Bybels-) eskatologies. Alles waarvoor die Dopers - 'tweelingbroer' van die Gereformeerdes volgens Noordmans (1979: 464) - gestaan het, was ook nie net sleg nie: hulle vroom lewenstyl, hulle liefde vir God en die naaste, hulle passie vir die koms van die koninkryk, hulle strewe na heiligheid in die kerk, hulle eerbied vir die Skrif en aksent op die Bergrede, is alles aspekte wat in die Reformatoriese teologie en etiek van fundamentele belang is. Noordmans (1980: 297) oordeel selfs dat '. . . de doperse onrust mag in calvinistische landen nooit geheel tot rust komen'. Waar die Doperse teologie egter skeef ontwikkel het, is in hulle dualisme van kerk en wêreld, asof die koninkryk van God nie ook in die samelewing moet gestalte aanneem nie; hulle fanatieke antisipasie van die koninkryk, asof die koms daarvan (ook) van die méns afhanklik sou wees; hulle program van politieke asketisme, asof die Christen se roeping net in kerkdiens geleë sou wees; in kort hulle skewe siening op die verhouding van die twee ryke, wat gewissel het van dualisme tot confusio.

Christus het immers nie sy navolgers opdrag gegee om uit die wêreld weg te vlug nie, maar om in die wêreld soos sout en lig te wees (Matt 5: 13-16); Hy bid nie om onttrekking aan die wêreld nie, maar dat hulle van die Bose bewaar sal word (Joh 17: 15); die goeie saad en slegte saad 
groei nou nog sáám en word eers in die oestyd geskei (Matt 13: 24-30). Paulus bevestig dit dat as 'n gelowige sou meen om nooit met wêrelddinge en sondaars kontak te hê nie, hy uit die wêreld sou moes weggaan (1 Kor 5: 9-10). En as owerheidsgesag so nou aan God verbind word (Rom 13: 1-7), kan deelname daaraan tog moeilik uit die Bose wees.

Dat daar in die latere Pinksterbeweging bepaalde verskuiwings, onder invloed van die Reformatoriese teologie plaasgevind het, kan seker moeilik ontken word. Die dualisme van die sestiende eeu is minder absoluut hanteer en daar het meer ruimte gekom vir die aanvaarding van die staat en die verantwoordelikheid van die kerk teenoor die staat. Alhoewel Pinkstermense 'n kritiese afstand tussen kerk en wêreld sal bewaar en aartsvyande van 'n volksteologie is, sal hulle nogtans '... probeer om die beginsels van die koninkryk in die wêreld toe te pas', hulle sal in die samelewing 'God se instrument van versoening' probeer wees (Nico Horn in Beeld, 12 Mei 1987). Maar hiermee is reeds ver weg beweeg van die heel vroegste dualistiese Pinksterdenke.

\subsection{Die rewolusionêr-eskatologiese model}

Dit kan onmoontlik ons bedoeling wees om hier ook maar enigsins te probeer om ' $n$ volledige beeld van die politieke teologie in sy verskillende gestaltes te gee. Om breedvoerig aandag te gee aan die teologie van die hoop (Moltmann), politieke teologie (Metz), teologie van die rewolusie (Shaull), Swart teologie (Cone), teologie van bevryding (Gutierrez) en feministiese teologie sou te veel plek opneem (vgl Jonker 1987: $128 \mathrm{vv}$ ). Ons bedoeling is veel eerder om kortliks die antwoord van die politieke teologie op die twee ryke-leer na te gaan. Opvallend is dat voorstanders van hierdie teologie uit feitlik alle konfessionele rigtings afkomstig is.

Hierdie teologie verset hom teen 'n piëtistiese benadering waar die primêre aandag van die kerk gerig is op die bekering van die indiwidu, terwyl die strukture wat die mens verkneg, verontagsaam word. Dit is 'n reaksie teen 'n restourasie-teologie wat die status quo verdedig en die skeppingsordeninge verabsoluteer. Dit is 'n reaksie teen 'n kerk wat weier om sy profetiese roeping uit te leef. Daarom word die fokus gerig op die strukture, eerder as op die enkeling, op verandering (rewolusie selfs), eerder as op die status quo, op die eskatologie, eerder as op die 
historie. Dat Marxistiese en neo-Marxistiese idees, veral ten opsigte van maatskappykritiek, hier 'n rol speel, word geredelik aanvaar.

Gewoonlik word die voordrag wat R Shaull in 1966 te Genéve oor rewolusie in teologiese perspektief gehou het, gesien as die begin van hierdie nuwe benadering. Tog was dit die opspraakwekkende boek van J Moltmann oor die 'teologie van die hoop' wat hierdie gedagtes in ' $n$ grootse teologiese ontwerp saamgevat het. Die verhouding kerk en samelewing kom nou in 'n nuwe lig te staan. God skep 'n nuwe, belofteryke toekoms en Hy roep die kerk daartoe op. Die kerk as kerk van die uittog, kan dus nooit met die bestaande orde tevrede wees en hom onkrities daarby neerlê nie. Die missionêre roeping van die kerk tot die wêreld raak nie net indiwiduele bekering nie, maar ook sosiale vernuwing: die verwerkliking van die reg, die humanisering van die samelewing en die sosialisering van die mensheid. Die tema van (wêreld-) 'verandering' loop soos 'n goue draad deur die boek van Moltmann: Dit gaan nie om die verhéérliking van die werklikheid nie, maar juis om die verándering daarvan (Moltmann 1969: 101); vir 'n teoloog gaan dit nie slegs om een of ander interpretasie van die wêreld, die geskiedenis en die mensheid nie, maar om verandering daarvan deur die verwagting van 'n Goddelike verandering (Moltmann 1969: 68). Die konsep van die koninkryk van God speel hier 'n deurslaggewende rol, en wel verstaan as enersyds God se heerskappy oor die mens, maar andersyds ook as God se ryk wat 'n allesomvattende eskatologiese grootheid is (Moltmann 1969: 195). Die kerk het vanselfsprekend met die wêreld te doen, dus ook met armoede, lyding en onderdrukking. 'Kerk vir die wêreld' beteken immers 'kerk vir die koninkryk'. Die Christendom is nie 'n wêreldveragtende religie nie, maar 'n religie van toekomsverwagting. In sy latere werke sou Moltmann hierdie idees nog verder uitwerk.

Later sou ander teoloë nog veel radikaler formuleer as wat by Moltmann die geval was en sou van die kerk eintlik 'n agent van die rewolusie gemaak word. Veral in sekere vorme van Swart teologie is dit duidelik te sien, byvoorbeeld in Canaan Banana (1981) se The Gospel according to the ghetto. Hier het ons 'n skoolvoorbeeld van hoe Christus voor die rewolusie-karretjie ingespan word. Die eerste ontwerp van ' $n$ Swart teologie stam natuurlik uit Amerika en is van die hand van James Cone. Witvliet (1984) het hierdie teologie in kaart probeer bring.

In Suid-Afrika het Basil Moore (1973) 'n begin daarmee gemaak. Maar ander het dit ook ter sprake gebring, soos M Motlabi, L Kretzschmar en 
J Mosala en B Tlhagale. In ten minste vyf proefskrifte is die tema aangeraak: A Boesak (1976), S Govender (1982), LRL Ntoane (1983), TA Mofokeng (1983) en SP Govender (1987). Sonder twyfel moet aartsbiskop Desmond Tutu en dr Allan Boesak vandag gesien word as twee van die eminentste vertolkers van hierdie teologiese rigting.

Boesak verkwalik die Westerse teologie sy kompartementalistiese en dualistiese denke, 'n denke wat so vreemd is aan die Bybelse en Afrika-eenheidsdenke (1977: 111). Hy wys daarop dat relevante prediking etiese (politieke) prediking is, aangesien die heerskappy van Christus vir alle terreine, dus ook die politiek geld (Boesak 1979: 9-14; 1986: 61). Daarom sal 'n prediker nie 'oor apartheid' preek nie, maar wel 'oor die apartheidsituasie' en alle fasette daarvan (Boesak 1979: 15). 'Die prediker sal nie probeer om politieke formules uit te werk en dit in die kele van die gemeente af te forseer nie' (Boesak 1979: 16). 'n Sentrale tema vir Swartmense is bevryding (Boesak 1977: 107; vgl 18, 19, 34), transformasie van die samelewing. 'This revolution need not necessarily be violent' (Boesak 1977: 114), hoewel soms 'a situation may arise' dat daar geen ander moontlikheid meer oop is nie (Boesak 1977: 58), maar dit kan slegs deur Swartmense beoordeel word (Boesak 1977: 56). Boesak waarsku teen die gevaar dat kontekstuele teologie deur die konteks oorspoel kan word (Boesak 1977: 112) en dat die evangelie met een of ander ideologie verknoop sal word (Boesak 1977: 96; 1986: 66) 'n gevaar wat in sy eie teologiese beskouinge nie denkbeeldig is nie. So word deur 'n onpartydige waarnemer (HDW Vox Reformata, Nov 1985: $54-55$ ) in ' $n$ boekresensie van ' $n$ preekbundel van Boesak, Walking on thorns, gesê dat 'Boesak is in danger of reducing the Gospel to a message of political and social liberation'.

In Suid-Afrika het die Swart teologie waarskynlik sy rypste uitdrukking gevind in die Kairos Dokument wat in 1985 verskyn en in 1986 hersien is.

Van die kant van 'Wit' teoloë het kritiek teen die Swart teologie in sy Suid-Afrikaanse gewaad - en Bosch (1974: 97-106) is van oordeel dat daar ten minste vyf strominge is - natuurlik nie uitgebly nie. Hierdie kritiek het ongelukkig nie altyd aan bepaalde eensydighede en oorreaksie ontkom nie. Dit neem egter nie weg nie dat daar naas elemente van waardering (vgl Floor sa: 130, 142) ook fundamentele kritiese vrae aan die politieke teologie gestel kan word.

Die eerste belangrike vraag is of die politieke teologie nie self weer ' $n$ politieke ideologie word nie (vgl Witvliet 1984: $323 \mathrm{vv}$ ). Word God en Christus, die Skrif en die kerk nie misbruik vir 'n bepaalde politieke 
ideologie nie (vgl Heyns 1975)? En verder: is die eskatologiese perspektief, met inbegrip van die 'eskatologiese voorbehoud', altyd suiwer bewaar (Engelbrecht 1978: 113)? Word die koninkryk van God nie alte veel met 'n "Swart" koninkryk geïdentifiseer nie? Word die twee koninkryke nie te veel vermeng nie (Engelbrecht 1978: 56; Hoek 1982: 298)? Is dit nie die fout van die radikale Christendom dat dit uit is op 'n nova creatio in plaas van 'n recreatio nie (Van Ruler 1971: 153)? Verder: is die soteriologie ongeskonde gehou sodat slegs Chrístus die enigste Verlosser is? Of moet die verontregte homself verlos, miskien nog met die hulp van Christus? Sit daar nie 'n gevaarlike stuk legalisme en sunergisme in die politieke teologie nie (vgl Bosch 1979: 217)? Is die leer oor die sonde nie te oppervlakkig en die leer oor die mens te optimisties nie? Is die koninkryk van God nie nog sneller as 'n rewolusie om aan die bestaande orde 'n einde te maak nie (Noordmans 1980: 115)? En as dit waar is dat die teologiese regverdiging van apartheid ' $n$ teologiese kettery is, is dit dan nie ewe waar dat die teologiese regverdiging van 'n rewolusie óók' $n$ kettery is nie (vgl egter Boesak 1977: 58)?

\section{3. 'N SUID-AFRIKAANSE KONTEKS}

'n Besoekende Lutherse teoloog het by geleentheid opgemerk dat Suid-Afrika deurgaan vir 'n Calvinistiese land, maar dat hy nêrens anders ter wêreld soveel deurwerking van die Lutherse twee ryke-leer as in Suid-Afrika gesien het nie. Of, om 'n kontrasterende siening aan te haal: 'In Zuid-Afrika heerst immers geen Lutherse twee-rijkenleer, maar een Gereformeerde pseudotheocratie, waarin niet, zoals Calvijn beoogde, de vrije kerk aan de vrije staat profetisch het gebod van God voorhoudt, maar waarin kerk en staat door dezelfde nationalistischracistische ideologie worden beheerst en elkaar de bal toespelen' (Berkhof 1985a: 135).

Wat heers in Suid-Afrika, in gereformeerde/hervormde Suid-Afrika? Heers daar ' $n$ twee ryke-leer en in watter gestalte? Heers daar dalk 'n bepaalde vorm van ' $n$ twee ryke-leer in die teologiese besinning en 'n totaal ander vorm in die politieke praktyk? En is daar sodoende sprake van ' $n$ dubbele dualisme? Hoe sien die Afrikaanse kerke die verhouding van kerk en volk byvoorbeeld? Verraai die wyse waarop onder leiding van die drie Afrikaanse kerke eie volkskerke of volkerekerke ontwikkel het, nie 'n skewe siening ten opsigte van die verhouding 
natuur en genade, volk en kerk nie? Struktureer die volk die kerk nie in 'n te hoë mate nie? Dreig die natuurorde nie om die genadeorde op te slurp nie, veral wanneer beweer word dat 'die kerk nie ewigheidsbestemming het nie, die nasies wel' (Van den Berg 1984: 32)? Is dit nie die kernprobleem in byvoorbeeld die dokument Geloof en Protes (1987) nie?

Miskien is dit in hierdie verband goed om na enkele gedagtes van BJ Engelbrecht te gaan kyk. Dit is duidelik dat hy hom tuisvoel in die gedagteklimaat van Calvyn in verband met die verhouding van kerk en staat (Engelbrecht 1979a: 23, 28, 29). Hy onderskei volk van God (kerk) en eie volk (Engelbrecht 1979a: 137-138) en aanvaar volkskerke (Engelbrecht 1979a: 140) - soos hy trouens meen ook Calvyn gedoen het (Engelbrecht 1979a: 29). Hy aanvaar ook nie net die verskeidenheid van volkskerke as God-gewil nie, maar ook die verskeidenheid van kerke binne een volk (Engelbrecht 1978c: 289). Hy waarsku teen die gevaar van verafgoding van eie nasie wat syns insiens gelukkig nog nie in Suid-Afrika plaasvind nie (Engelbrecht 1979a: 136).

Engelbrecht oordeel dat een van die basiese Skrifperspektiewe van die Calvinisme daarin geleë is dat die geloof van die hart in alle fasette van die lewe uitgeleef moet word; hierdie lewe en werklikheid moet vanuit die Woord van God krities besien en gerelativeer word (Engelbrecht 1978c: 272). Die kerk preek nie een of ander staatsorde nie, maar die koninkryk van God en staan krities en genesend teenoor élke stelsel (Engelbrecht sa: 271). Die kerk preek die hemelse en ewige dinge '. . . en dan sal die Evangelie self soos suurdeeg die sosiale verhoudinge geleidelik deursuur' (Engelbrecht 1964: 37). Daarom is dit begryplik dat hy kan beweer dat die Nederduitsch Hervormde Kerk van Afrika '. . . wou nooit ten opsigte van die openbare en politieke lewe die offisiële protesteerder wees nie, veral nie 'n drukgroep nie' (Engelbrecht [1978a]: 20). Kuyper se dualistiese kerkbeskouing word gekritiseer omdat dit op 'n neutrale staat moet uitloop (1979a: 30; [1979b]: 20)!

Vir die teologiese insigte van Barth het Engelbrecht besondere waardering. Hy het diegene wat hier eenkant gaan staan het, verkwalik omdat ' . . by hulle die kragtige en gesondmakende invloed van Barth verbygegaan het' (1978c: 199). Die vraag is natuurlik presies hoe die 'kragtige en gesondmakende invloed' van Barth in die Hervormde teologie (en kerk) in Suid-Afrika gestalte aangeneem het. Sou Barth ooit te vinde kon wees vir 'n volkskerk in sy Suid-Afrikaanse gestalte?

Trouens, dis opvallend dat juis op die punt van die twee ryke-leer so min van die gedagtes van die twee groot Nederlandse Hervormde teoloë, AA van Ruler en O Noordmans, deurgewerk het in die Her- 
vormde teologie. Dis waar dat Van Ruler (1972: 140) kan sê dat die kerk '. . van pure katholiciteit ook nationaal van aard is; $z i j$ is volkskerk'. Maar weer eens, sou hy ook kon saamstem met die spesifiek SuidAfrikaans gestalte daarvan, met geslote lidmaatskap en al (vgl Koekemoer 1987)?

Ons kan van Noordmans (1980: 125) leer dat die kerkdeure vir elkeen oopstaan en dat elke goeie preek die middelmuur van skeiding verbreek (Noordmans 1980: 146); ' . . de kerk ... kan niet staan op de grondslag van bloed of ras' (Noordmans 1956: 39).

Ek besef terdeë dat daar onder die Hervormde teoloë in Suid-Afrika verskil van mening oor die volkskerk is, selfs tussen hulle wat hierdie konsep aanvaar. Die dringende vraag ontstaan waarom daar veral van buite soveel verset is teen die volkskerkmodel, juis in sy SuidAfrikaanse gestalte. En so min kritiek van binne (vgl Van der Merwe 1986: 314-338). Waarom het Hervormde teoloë, wat nie vasgevang was in Kuyper se dualistiese kerkbegrip nie, nie 'n veel sterker getuienis in die samelewing laat uitgaan nie?

Soos meeste Afrikaanse teoloë het Engelbrecht tereg by die sentrale temas in die denke van Calvyn probeer aansluiting vind. Die groot probleem by Afrikaase teoloë is egter dat met ' $n$ formele aansluiting volstaan word sonder nadere konkretisering in die spesifiek SuidAfrikaanse konteks. Daarmee is die gevaar van 'n soort natuurlike teologie waarin die bytende effek van die evangelie (sout!) afgestomp is, wawyd oop. In hierdie verband kan ons gerus luister na 'n uiters belangrike opmerking wat Engelbrecht ([1978a]: 23) - wel in ' $n$ ander verband - gemaak het: 'Ek begin al hoe meer oortuig raak dat daar in die Christelike Etiek die meeste gesondig word, nie aan die kant van die Skrif en Skrifgebruik nie, maar aan die kant van die noukeurige en objektiewe vastelling van die sake wat beoordeel moet word'. Is een van die grootste leemtes van Afrikaanse teoloē nie juis dat ons die volle Suid-Afrikaanse konteks maar swak ken nie?

\section{SAMEVATTING}

Indien ek enkele samevattende opmerkings rondom die vraagstuk van die twee ryke-leer moet maak, sou ek graag op ten minste die volgende vier basiese aspekte wou wys:

\subsection{Daar is net één Koning}

Aan Jesus Christus is álle mag in hemel en op aarde gegee (Matt 28: 18). Die belydenis 'Jesus is die Here (Kúrios)', is een van die oudste 
Christelike belydenisse, uitgespreek in 'n politieke konteks van 'keiser kúrios' (vgl 1 Kor 12: 3, 2 Kor 4: 5, Rom 10: 9, Fil 2: 11). Die Skrif teken Christus as Hoof van die kerk èn kosmos (Ef 1: 10, 21, 22; Kol 2: 10).

Hierdie een Koning het deur sy kruisiging en opstanding álle bose magte in hemel en op aarde oorwin. 'Hy het die bose magte ontwapen en hulle in die openbaar vertoon deur hulle as gevangenes in die triomftog van Christus mee te voer' (Kol 2: 15; vgl Joh 12: 31; 16: 33; 1 Kor 15: 24-26; Heb 2: 14). Oor hierdie ontmagtiging van die magte en ontdemonisering van die wêreld deur Christus mag nooit geringskattend geoordeel word nie. Tereg merk Moltmann (1984: 136) op dat die fundamentele teologiese vraag aan die twee ryke-leer dit is dat daarin uitgegaan word van die stryd tussen geloof en ongeloof, God en Satan, maar nie van die oorwinning van God in Christus oor die sonde, dood en duiwel nie. Dié stryd kan nie ontken word nie (Ef 6: 12-13), maar eweneens nie dat die gelowiges in Christus hiper-oorwinnaars is nie (Rom 8: 37).

\subsection{Daar is net éěn Koninkryk}

Uit bostaande vloei eintlik logies voort dat net van één koninkryk, naamlik die koninkryk van God, gepraat moet word. Alle dualistiese denke, wat die werklikheid in 'n Godsryk en Satansryk/wêreldryk opdeel, moet van die hand gewys word (so bv Douma 1984: 87, 148; Van der Walt 1981: 260-265; Troost 1980: 81-85). God se heerskappy gaan oor kerk èn wêreld en téén die mag van die duiwel. Skepping en verlossing, natuur en genade vorm nie 'n dualisme nie, maar wel 'n dualiteit. As daar dan van 'n 'tweërlei burgerskap' by gelowiges gepraat word (Floor 1981: 81-83), dan moet dit nie in terme van die Griekse metafisiese denke verstaan word as 'hemelse burgerskap' teenoor 'aardse burgerskap' nie, maar in Bybels-eskatologiese sin as burgersvan-die-ou-aarde en burgers-van-die-nuwe-aarde. As Christus dus vir Pilatus sê dat sy koninkryk nie 'van hierdie wêreld' is nie (Joh 18: 36), dan is die strekking tog baie duidelik dat sy koninkryk nie 'vanuit hierdie wêreld' is nie. Dit kom nie vanuit die sondige mens op nie, word nie van onder af opgebou nie, maar word uiteindelik deur God geskenk en kom dus van Bo. Maar dit beteken hoegenaamd nie dat dit, al kom dit van Bo, nie op aarde onder mense gestalte aanneem nie. Inteendeel. Ons sou dus ook van die koninkryk van God as 'n 'wêreldlike koninkryk' kon praat wat natuurlik iets anders is as 'n 
'wêreldse koninkryk'. 'De drie-enige God houdt er geen mondiaal apartheidsbeleid op na' (Beker \& Hasselaar 1981: 283).

Mag ons dan glad nie meer praat van 'n 'koninkryk van Satan' nie, van 'die duiwel en sy hele ryk' nie (Gebed in die Doopsformulier)? Myns insiens kan ons nie anders daaroor praat as in openbaringshistoriese en eskatologiese perspektief nie ( $v g l$ Coetzee, in Du Toit 1969: 76-95). Die Skrif praat wel van die 'owerste van die wêreld' (Joh 12: 31; $14: 30 ; 16: 11$ ) en van die 'god van hierdie wêreld' ( 2 Kor $4: 4$; vgl Ef 2: 2), maar dan binne die konteks van 'n oordeel wat voltrek is (Joh 12: 31 ; 16: 11) en van ' $n$ duiwel wat onttroon is (Kol 2: 15, Op 11: 15, 17) - wat natuurlik nie beteken dat die duiwel nie nog groot mag en invloed het nie (1 Pet 5: 8; 1 Joh 5: 18-19; Op 12: 2).

Maar van twee gelykwaardige ryke, nee, daarvan leer die Nuwe Testament ons niks. Dit is vanuit die Christologie en die pneumatologie nie meer moontlik nie (Matt 12: 28). Is kerk en wêreld, kerk en staat, dan identies? Is daar nie baie duidelik 'n keiserryk en 'n Godsryk nie (Matt 22: 21)? Natuurlik mag ons hier 'n verantwoorde onderskeiding aanbring. God regeer nie oral op dieselfde wyse nie (Douma 1984: 148; Beker \& Hasselaar 1981: 283). Die modus van die heerskappy binne en buite die kerk verskil (Theron 1982: 127). Die rede daarvoor is nie dat God dubbelslagtig is nie, maar wel omdat die méns vanweë die sonde en ongehoorsaamheid so tweeslagtig is. Die 'keiserryk' funksioneer ook nie buite of langs die Godsryk nie, maar daarbinne, omdat die Godsheerskappy oor álles gaan. Daar is net één ryk maar baie regimente.

Ons moet nie simplisties tussen koninkryk en wêreld as twee ryke of tussen kerk en staat as twee regimente onderskei nie. Die skepping is veelvormig en die samelewing pluraal. Daar is talle organisasies, sisteme, strukture, samelewingsverbande (vgl Troost 1980: 83). God heers oor almal. Wel nie altyd op 'n transparante wyse nie, maar tog. Ondubbelsinnig heers $\mathrm{Hy}$ in sy kerk wat 'n stukkie gerealiseerde koninkryk op aarde is en daarom juis die koninkryk in die volle lewe moet inlei (Matt 5: 13-16). Deur eksemplariese bestaan en profetiese kritiek, deur evangelieverkondiging en diakonale uitreiking, lewer die kerk ' $n$ getuienis in en aan die samelewing dat God op heilsame wyse werksaam is totdat $\mathrm{Hy}$ uiteindelik alles nuut gemaak het en alles in almal is. Dit doen God nie deur die aardse werklikheid te vernietig nie, ook nie deur dit te vervolmaak nie, maar deur dit, deur die oordeel heen, te vernuwe. Die nuwe aarde wat ons verwag is hierdie, maar hernude, aarde (2 Pet 3: 13). Ons eindbestemming is nie in die hemel nie, maar op die nuwe aarde (Op 21: 2). 
Ook die staat en owerheid staan in diens van die koninkryk, soms bewustelik, soms onbewustelik. Goeie staatkunde en goeie politiek moet dus trag om iets van die beginsels van die koninkyk te realiseer, moet dus streef na vrede en versoening, vryheid en geregtigheid. Die aard en graad van hierdie realisering sal in die kerk anders daar uitsien as in die staat (vgl Theron 1982: 125), ewige heil is nie identies aan politieke heil nie, maar 'n neerslag daarvan moet in die politiek sigbaar word. Dit blyk ook duidelik uit Paulus se woorde in Romeine 12: 18: 'As dit moontlik is, sover dit van julle afhang, leef in vrede met alle mense' (vgl Heb 12: 14). Die etiese eise van die koninkryk van God geld ook vir die politiek (Floor 1974: 19).

\subsection{Daar is net één koninkrykswoord}

Daar is net één Woord van God wat vir die volle lewe geld (Ps 119: 105; 2 Tim 3: 16-17). Dit is nie waar dat die owerheid met die wet werk en die kerk met die evangelie nie. Beide wet en evangelie geld kerk en staat (Velema 1987). Die wet van God is onmisbaar vir ' $n$ verantwoordelike samelewing (vgl Douma 1984: 165-168).

In die prediking van die Woord word die volle lewe belig - van die politiek tot die partypolitiek. Om te sê dat predikante 'nie politiek mag preek nie' is natuurlik korrek; om te sê dat hulle nie 'oor die politiek mag preek nie' is foutief. Want dit sou dan daarop neerkom dat daar maar weer 'n deel van die lewe (die politieke deel) onttrek word aan die beligting van die Woord. En dit is onhoudbaar. So 'n tipe Skrifprediking sal egter verskil van 'politieke prediking' waar die evangelie eintlik omgebuig word tot politieke toespraak met 'n sekulêre bevrydingsboodskap. So 'n prediking sal veral aandag gee aan die morele grondslae en gehalte van die heersende politiek. En dit spreek vanself dat so ' $n$ profetiese prediking nie net gebring sal word deur indiwiduele predikers nie, maar ook deur sinodale kerkvergaderings soos so duidelik in (die vergete) Artikel 28 van die Dordtse Kerkorde gereël word.

Om daarom van 'soewereiniteit in eie kring' ten opsigte van die verskillende samelewingsverbande te praat, kan myns insiens veel misverstand wek. Geen terrein kan soewerein (of outoritêr) wees nie (vgl Douma 1984: 123, 149). Alle terreine op aarde word gerelativeer deur die koningsheerskappy van Jesus Christus en die gesag van sy Woord. Dit is juis een van die probleme van die twee ryke-leer dat die Eigenständigkeit maklik in 'n Eigengesetzlichkeit kan ontaard (Theron 
1985: 49). Wel kan daar ten opsigte van die verskillende terreine van eie funksies en bevoegdhede sprake wees, maar dan steeds in interrelasionele konteks en onder beligting van die één Woord.

\subsection{Daar is net één koninkrykslewe}

$\mathrm{Al}$ leef die kind van God in ' $\mathrm{n}$ plurale samelewing en in verskillende verbande, mag hy geen dubbele lewe voer nie (vgl Barth 1969: 593). Hy dien één Koning in één koninkryk en hy gehoorsaam één Woord. Hy word gevolglik opgeroep om álles tot eer van God te doen, in die kerk, maar ook in die politiek (1 Kor 6: 31). Wat Christene, selfs slawe, moet doen, moet hulle van harte doen, 'soos vir die Here' (Kol 3: 23).

Dat daar in 'n sondige bedeling soms ' $n$ kompromis aangegaan sal moet word, is onvermydelik. Dit mag egter nooit ' $n$ lewenstyl word en daarin mag ook nooit berus word nie. ' $n$ Christelike lewenstyl moet die stempel dra van die nuwe mens in Christus ( 2 Kor 5: 17), die mens wie se ganse lewe beheers word deur die Gees en nie deur die vlees (sy ou natuur) nie (Rom 12-13; Gal 5; Ef 4-5).

Ek sluit af: Augustinus het sy boek oor die koninkryk van God in Noord-Afrika geskryf toe die Romeinse Ryk aan 't verkrummel was. Dit is heilsaam dat ons in Suid-Afrika, noudat die Suid-Afrikaanse ryk aan 't wankel is, opnuut herinner word daaraan dat daar net één onverganklike en onoorwinlike koninkryk is: Die koninkryk van God (Dan 2: 44).

Graag wil ek by hierdie geleentheid my hartlike wense uitspreek teenoor prof BJ Engelbrecht by geleentheid van aanvaarding van sy emeritaat, met die bede dat die Here hom en sy huis verder ryklik sal seën.

\section{Literatuurverwysings}

AALDERS, PFT ea 1973. Woord en werkelijkheid: Over de theocratie. Nijkerk: Callenbach. AUGUSTINUS, A 1983. De stad van God. Vertaal deur Gerard Wijdeveld. Baarn: Ambo. Gerard Wijdeveld. (Gesiteer volgens die boekdele van die De Civitate Dei).

BALKE, W 1977. Calvijn en de Doperse radikalen. 2de Druk. Amsterdam: Ton Bolland. BANANA, C 1981. The Gospel according to the ghetto. 2nd Edition. Gwelo: Mambo.

BARTH, K 1945. Eine Schweitzer Stimme 1938-1945. Zürich.

BARTH, K 1946. Christengemeinde und Bürgergemeinde. Zürich.

BARTH, K 1969. Kirchliche Dogmatik, III 4. 3. Aufl. Zurich: EVZ-Verlag.

BEKER, EJ \& HASSELAAR, JM 1981. Wegen en kruispunten in de dogmatiek, 3: Christologie.

Kampen: Kok.

BERKHOF, H 1973. Christelijk Geloof: Een inleiding tot de geloofsleer. Nijkerk: Callenbach. 
BERKHOF, H ea 1985a. Met de moed der hoop: Opstellen aangeboden aan dr CF Beyers Naudé. Baarn: Ten Have.

BERKHOF, H 1985b. 200 Jahre Theologie: Ein Reisebericht. Neukirchen: Neukirchener Verlag.

BOESAK, A 1977. Farewell to innocence: A social-ethical study of black theology and black power. Johannesburg: Ravan.

BOESAK, A 1979. Die vinger van God: Preke oor geloof en die politiek. Johannesburg: Ravan.

BOESAK, A 1984a. Walking on thorns: The call to christian obedience. Geneva: WCC.

BOESAK, A 1984b. Black and Reformed: Apartheid, liberation and the Calvinist tradition. Johannesburg: Skotaville.

BOESAK, A 1986. Als dit verraad is ben ik schuldig. 2de Druk. Baarn: Ten Have.

BONHOEFFER, D 1966. Ethik. München: Kaiser.

BONHOEFFER, D 1970. Widerstand und Ergebung. München: Kaiser.

BORNKAMM, H 1966. Luther's doctrine of the two kingdoms. Philadelphia: Fortress.

BOSCH, DJ 1974. Het evangelie in Afrikaans gewaad. Kampen: Kok.

BOSCH, DJ 1979. Heil vir die wêreld: Die Christelike sending in teologiese perspektief. Pretoria: NG Kerkboekhandel.

BOTHA, SJ 1973. Die volkskerk. Pretoria: HAUM.

BUYS, PW 1970. Die ekklesiologiese onderskeiding organisme en instituut as antwoord op die problematiek van die volkskerk: 'n Historiese, prinsipiële en praktiese studie. Potchefstroom. (Ongepubliseerd).

CALVYN, J sa. Institutie of onderwijzing in de christelijke godsdienst, I-lll. 3de Druk. Delft: Naamloze Vennootschap WD Meinema. (Aangehaal as boekdeel, hoofstuk en paragraaf).

DANTINE, W 1973. Thesen zur 'Zwei-Reiche-Lehre'. Zeitschrift fur Evangelische Ethik $17 / 1,26-29$.

DOUMA, J 1966. Algemene genade. Goes: Oosterbaan \& Le Cointre.

DOUMA, J 1984. Politieke verantwoordelijkheid. Kampen: Van den Berg.

DREYER, PS (red) 1977. Afrikanerliberalisme. Arcadia: Boekenhout.

DUCHROW, U 1970. Christenheit und Weltverantwortung: Traditionsgeschichte und systematische Struktur der Zweireichelehre. Stuttgart.

DURAND, JJF 1978. Kontemporêre modelle vir die verhouding van kerk en samelewing in Voster, WS (red), Kerk en samelewing, 12-36. Pretoria: Unisa.

DU TOIT, $S$ ea (red) 1969. Die koninkryk van God. Potchefstroom.

DUVENAGE, SCW 1962. Die verhouding van kerk tot volk: 'n Histories-prinsipiële studie. Zaendijk: Heijnis.

EBELING, G 1980. Luther: An introduction to his thought. 3rd Edition. Philadelphia: Fortress.

ENGELBRECHT, B 1978. God en die politiek. Durban: Butterworth.

ENGELBRECHT, B 1982. Ter wille van hierdie werreld: Politiek en Christelike heilsbelewing in Suid-Afrika. Kaapstad: Tafelberg.

ENGELBRECHT, B 1985. Augustinus se politieke "realisme" en sy "neutrale" definisie van die staat, in Oorspronge in oënskou: Opstelle oor die vroeë kerk ter ere van JAAA Stoop op sy sestigste verjaardag. Pretoria: Unisa.

ENGELBRECHT, B 1986. Die tweeheid van Kerk en staat. Johannesburg: Perskor.

ENGELBRECHT, BJ sa. Die wet van God, in Geloofsleer en sedeleer vir Standerd 10, 213-287. Pretoria: HAUM.

ENGELBRECHT, BJ 1964. Die kommunistiese aanslag op die kerk, in Christendom teen Kommunisme: Referate gelewer by die volkskongres oor kommunisme, 24-55. Pretoria.

ENGELBRECHT, B] [1978a]. Opmerkings rondom die basiese probleme van die teologiese etiek. HTS 34/3, 13-23.

ENGELBRECHT, BJ [1978b]. Nuwere ontwikkelings op die gebied van die Sistematiese Teologie. HTS 34/4, 45-69. 
ENGELBRECHT, BJ 1978c. Teologie in die kerk: Artikels en opstelle uit 'n kwarteeu van teologiese arbeid. Uitgegee onder redaksie van JP Oberholzer. Pretoria: HAUM.

ENGELBRECHT, BJ 1979a. Temas rondom die Reformasie: Artikels oor die Reformatore en ons Reformatoriese belydenis en erfenis. Pretoria: HAUM.

ENGELBRECHT, BJ [1979b]. Calvin and the Corpus Christianum. HTS 35/1, 11-21.

ENGELBRECHT, BJ 1980. God, die Heilige Gees. Pretoria: HAUM.

ENGELBRECHT, BJ 1987. 'n Nuwe ekumeniese geloofsbelydenis? HTS 43, 72-85.

FLOOR, B 1974. Die koninkryk van God en die vernuwing van die maatskappy. Potchefstroom: Pro Rege.

FLOOR, L 1981. Die evangelie van die koninikryk: 5 aspekte. Pretoria: NG Kerkboekhandel.

FLOOR, L sa. Die exodus-motief in die swart teologie, in Die saailand is die wêreld. Hammanskraal: HTS.

GEYSER, AS ea [1960]. Vertraagde aksie: 'n Ekumeniese getuienis uit die Afrikaanssprekende kerk. Pretoria: NG Kerkboekhandel.

GOLLWITZER, H 1964b. Forderungen der Freiheit: Aufsätze und Reden zur politischen Ethik. 2. Aufl. München: Kaiser.

GOLLWITZER, H 1976. Forderungen der Umhehr: Beiträge zur Tehologie der Gesellschaft. München: Kaiser.

GOLLWITZER, H 1982. An introduction to protestant theology. Philadelphia: Westminster.

GREIVE, W 1987. 'Zweireichelehre' als Königsherrschaft Jesu Christi: Zur Verhältnisbestimmung von Kirche und Staat in der Entwicklung der Theologie Karl Barths. Kerygma und Dogma 33/2, 102-119.

HDW 1985. Oorsigartikel: Boesak, A, Walking on thorns. Vox Reformata Nov 1985.

HEYNS, JA 1975. Teologie van die rewolusie. Kaapstad: Tafelberg.

HOEK, J 1982. Luthers twee-rijken-leer, in Graafland, C ea (red), Luther en het gereformeerd protestantisme, 283-306's-Gravenhage: Boekencentrum.

JONKER, WD 1987. Die relevansie van die kerk: Aktuele teologiese reaksies op die vraag na die betekenis van die kerk in die wêreld. Stellenbosch. (Ongepubliseerde RGN-Verslag).

KAIROS THEOLOGIANS 1987. The Kairos Document: A theological document on the political crisis in South Africa. 4th Edition. Johannesburg: Skotaville.

KOEKEMOER, PJT 1987. AA van Ruler oor die volkskerk. Die Hervormer, Oktober 1987, bl 16.

KÖNIG, A 1979. The church and politics. Theologia Evangelica 12/1, 23-34.

KUITERT, HM 1985. Alles is politiek maar politiek is niet alles: Een theologisch perspectief op geloof en politiek. 2de Druk. Baarn: Ten Have.

KUITERT, HM 1987. De politiek in de theologie. Gereformeerd Theologisch Tijdschrift 87/1, 40-46.

KUYPER, A 1959. Het Calvinisme. 3de Druk. Kampen: Kok

LAU, F 1953. Luthers Lehre von den beiden Reichen. Berlin.

LUBBE, WJG ea 1987. Geloof en protes: 'n Antwoord namens beswaarde lidmate op sekere aspekte van 'Kerk en samelewing'. Pretoria: Voortsettingskomitee.

MARSHALL, M 1987. The restless heart: The life and influence of St Augistine. Grand Rapids: Eerdmans.

MOLTMANN, J 1969. Theologie van de hoop: Studies over de grondslagen en de konsekwenties van een christelijke eschatologie. 3de Druk. Utrecht: Ambo.

MOLTMANN, J 1984. Politische Theologie: Politische Ethik. München: Kaiser.

NEDERDUITSCH HERVORMDE KERK VAN AFRIKA 1985. Kerk en Wêreld 2000. Pretoria: Kital.

NOORDMANS, O 1956. Herschepping: Beknopte dogmatische handleiding voor godsdienstige toespraken en besprekingen. 2de Druk. Amsterdam: Holland.

NOORDMANS, O 1979. Verzamelde Werken, Deel Il. Kampen: Kok.

NOORDMANS, O 1980. Verzamelde Werken, Deel VIII. Kampen: Kok.

NOORDMANS, O 1986. Verzamelde Werken, Deel VI. Kampen: Kok. 
NÜRNBERGER, N 1975. Sistematiese teologie. Genadendal: Morawiese Boekdepot.

PANNENBERG, W 1981. Ethics. Philadelphia: Westminster.

PONT, AD 1986. Verbond en volkskerk. HTS 42, 28-76.

RENDTORFF, T] 1976. Dokumentation als Kirchenpolitik? Kritik einer Textsammlung zur

Zwei-Reiche-Lehre. Zeitschrift für Evangelische Ethik 20/1, 64-70.

RIDDERBOS, HN 1968. Het Woord, het rijk en onze verlegenheid. Kampen: Kok

ROOMS-KATOLIEKE KERK 1967. Constituties en decreten van hel Tweede Vaticaans Oecumenisch Concilie. Amersfoort: Katholiek Archief.

ROTHUIZEN, GTh 1962. Primus usus legis: Studie over het burgerlijk gebruik van de wet. Kampen: Kok.

ROTHUIZEN, GTh 1969. Aristocratisch christendom: Over Dietrich Bonhoeffer. Kampen: Kok.

ROTHUIZEN, GTh 1978. Kerk en politiek: Matteüs 20: 25-28 en de twee rijkenleer, in Grosheide, $\mathrm{HH}$ et al (red), De knechtgestalte van Christus: Studies door collega's en oud-leerlingen aangeboden aan prof $d r$ HN Ridderbos, 179-193. Kampen: Kok.

ROTHUIZEN, GTh 1985. Een spaak in het wiel: Dietrich Bonhoeffer over de vrede. Baar: Ten Have.

SAUTER, G et al 1973. Zur Zwei-Reiche-Lehre Luthers. München: Kaiser.

SCHARFFENORTH, G 1982. Den Glauben ins Leben ziehen . . München: Kaiser.

SCHELHAAS, N 1984. De politieke theologie van helmut Gollwitzer: Van Luther tot Marx. Kampen: Kok.

SCHREY, HH (Hrsg) 1969. Reich Gottes und Welt: Die Lehre Luthers von den zwei Reichen. Darmstadt.

SCHÜTTE, HW 1978. Zwei-Reiche-Lehre und Königsherrschaft Christi, in Hertz, A et al Handbuch der christlichen Ethik, I, 339-353. Gütersloher Verlagshaus Gerd Mohn.

SCHUURMAN, L 1965. Confusio regnorum: Studie zu einem Thema aus Luthers Ethik. Den Haag.

SMIT, JH 1982. Swart teologie, wit teologie en hermeneutiese beginsels. Bloemfontein: UOVS.

SMITH, N], O'BRIEN GELDENHUYS, FE, MEIRING, P (reds) 1981. Storm-kompas: Opstelle op soek na 'n suiwer koers in die Suid-Afrikaanse konteks van die jare tagtig. Kaapstad: Tafelberg.

SMITH, T 1987. Kansel en politiek: 'n Evaluering van die eietydse preekgestaltes van die politieke teologie. Kaapstad: Lux Verbi.

STEPHENSON, J 1985. Three orders, two governments and two kingdoms. Evangelium $12 / 23,66-81$.

THERON, PF 1982. Die vreemdheid van die kerk: 'n Reaksie op die ope brief, in Bosch, DJ et al (red),Perspektief op die Ope Brief. 123-132. Kaapstad: Human \& Rousseau.

THERON, PF 1985. Breuk of brug? Enkele opmerkings rondom die tema: kerk en wêreld, in Louw, DJ (red), Op die breuklyn. 43-54. Kaapstad: NG Kerk-Uitgewers.

THIELICKE, H 1965a. Theologische Ethik, I. Tübingen: Mohr.

THIELICKE, H 1965b. Theologische Ethik, II/1. Tübingen: Mohr.

THIELICKE, H 1966. Theologische Ethik, Il/2. Tübingen: Mohr.

THIELICKE, H 1968. Theologische Ethik, III. Tübingen: Mohr.

THIELICKE, H 1983. Glauben und Denken in der Neuzeit: Die grossen Systeme der Theologie und Religionsphilosophie. Tübingen: Mohr.

TREURNICHT, AP 1975. Credo van 'n Afrikaner. Kaapstad: Tafelberg

TROOST, A 1980. De leer der twee rijken. Beweging 80 44/6, 81-85.

VAN DEN BERG, CL [1961]. Onvertraagde Voortgang: Ope brief aan prof dr A van Selms. Pretoria: HAUM.

VAN DEN BERG, CL 1984. Kerk en politiek: Rekenskap. Pretoria.

VAN DEN BERG, J 1961. Twee regimenten, éen Heer. Kampen: Kok.

VAN DER MERWE, H 1986. Noordmans en die Duitse kerkstryd. NGTT 27/3, 314-338.

VAN DER MERWE, PJ 1982. 'Burgerlike godsdiens' in Suid-Afrikaanse konteks: Teologies 
en godsdiensweteskaplik oorweeg, in Oberholzer, JP (red), Die kerk in die wêreld, 193-203. Pretoria: HAUM.

VAN DER WALT, BJ 1981. Van Athene na Genéve: Kort oorsig oor die geskiedenis van die Wysbegeerte vanaf die Griekse tot die reformasie. Potchefstroom: Pro Rege.

VAN DER WALT, BJ (red) 1983a. Maarten Luther 1483-1983. Potchefstroom: PU vir CHO.

VAN DER WALT, BJ 1983b. Die staat in die lig van die Bybel. Potchefstroom: PU vir CHO.

VAN DER WESTHUIZEN, HG 1983. Ekumene: Marx of Markus? Pretoria: Kital.

VAN OORT, J 1986. Jeruzalem en Babylon. 's-Gravenhage.

VAN ROOYEN, JHP 1964.Kerk en staat: 'n Vergelyking tussen Kuyper en Van Ruler. Groningen: V R B Kleine.

VAN RULER, AA 1969. Theologisch Werk, I. Nijkerk: Callenbach.

VAN RULER, AA 1971. Theologisch Werk, III. Nijkerk: Callenbach.

VAN RULER, AA 1972. Ik geloof: De Twaalf Artikelen van het geloof in morgenwijdingen. 4de Druk. Nijkerk: Callenbach.

VAN RULER, AA 1973. Theologisch Werk, VI. Nijkerk: Callenbach.

VAN WYK, DJC (red) 1978. Stemme uit die verlede, I: Volkere-verhoudings in Suid-Afrika. Pretoria: HAUM.

VAN WYK, JA 1978. Teologie en ideologie. Sovenga. (Studiegroep 'Kerk en Wêreld'.)

VAN WYK, JH 1984. Etiek en vrede: 'n Teologies-etiese evaluering van die Christenpasifisme. Stellenbosch: Cabo.

VAN WYK, JH 1986. Gesindheid en gestalte. Pretoria: NG Kerkboekhandel.

VAN WYK, JH \& VORSTER, JM (reds) 1985. Altyd reformeer: Gesprekke oor politiek en godsdiens.

VAN ZYL, FJ 1987. Stemming word só teen Hervormde Kerk geskep. Die Hervormer Maart 1987 , bl 1.

VELEMA, WH 1974. Ethiek en pelgrimage: Over de Bijbelse vreemdelingschap. Amsterdam: Ton Bolland.

VELEMA, WH 1987. Wet en evangelie. Kampen: Kok.

WITVLIET, T 1984. De weg van de zwarte messias: De hermeneutische uitdaging van zwarte theologie als een theologie van bevrijding. Baarn: Ten Have.

WOLMARANS, HP 1968. Die gronde vir apartheid, I-III. Die Hervormer April-Junie 1968.

ZAHRNT, H 1967. Wachtend op God: De Duitse protestantse theologie in de twintigste eeuw. Utrecht: Ambo. 